\title{
Efficacy of biocontrol agents and organic amendments against root rot disease in blackgram
}

\author{
SOWMYA TETALI*, P. LAKSHMANAN AND P. BHARAT CHANDRA ${ }^{1}$
}

Department of Plant Pathology, Adhiparasakthi Agricultural College (T.N.A.U.), KALAVAI (T.N.) INDIA

${ }^{1}$ Department of Plant Pathology, Dr. Panjabrao Deshmukh Krishi Vidyapeeth, AKOLA (M.S.) INDIA

\section{ARITCLE INFO}

Received : 25.01 .2016

Accepted : 20.03.2016

\section{KEY WORDS :}

Trichoderma viride, Macrophomina phaseolina, Organic amendments

*Corresponding author:

Email: sowmyatetali@gmail.com

\section{ABSTRACT}

Trichoderma viride, the plant growth promoting fungi and increasing the soil fertility significantly controlled root rot disease caused by Macrophomina phaseolina. Use of Trichoderma viride along with neem cake produced the higher germination percentage and shoot length, respectively as compared to their separate use. Soil amendment with neem cake and seed treatment with TNAU isolate of $T$. viride significantly reduced the per cent disease incidence. Among the treatments, pots received with antagonist and organic amendments recorded lesser disease incidence than control.

How to view point the article : Tetali, Sowmya, Lakshmanan, P. and Chandra, P. Bharat (2016). Efficacy of biocontrol agents and organic amendments against root rot disease in blackgram. Internat. J. Plant Protec., 9(1) : 279-282. 